Hutchison, W. M., Dunachie, J. F., Siim, J. Chr., and Work, K. (1970). British Medical fournal, 1, 142.

Jacobs, L. (1967). Advances in Parasitology. London, Academic Press.

Kagan. I. G., and Norman, L. (1970). In Manual of Clinical Microbiology, ed. J. Blair, E. H. Lennette, and J. P. Truant, Chapt 51. Bethesda, American Society for Microbiology.
Lotze, J. C., Shalkop, W. T., Leek, R. G., and Behin, R. (1964). fournal of Parasitology, 50, 205.

Sabin, A. B., and Feldman, H. A. (1948). Science, 108, 660.

Sheffield, H. G., and Melton, M. L. (1970). Science, 167, 892.

Smetana. H. (1933). Archives of Pathology, 15, 330.

Zaman, V. (1970). South East Asian fournal of Tropical Medicine and Public Health, 1, 329.

\section{Immunoglobulin M Specific for Measles and Mumps in Multiple Sclerosis}

\author{
J. H. D. MILLAR, K. B. FRASER, \\ MARGARET HAIRE, J. H. CONNOLLY, \\ P. V. SHIRODARIA, DIANA S. M. HADDEN
}

British Medical fournal, 1971, 2, 378-380

\section{Summary}

Sera from 43 patients with multiple sclerosis were tested by immunofluorescence. Sera from patients with active multiple sclerosis included four with measles virus-specific immunoglobulin $M$ (measles $I g M$ ) and two with mumps virusspecific IgM (mumps IgM). In one case each mumps IgM and measles IgM seem to have persisted for two and a half years and three years respectively. In a comparable group of 43 patients with other nervous diseases measles IgM was found in only one serum, and among 43 normal patients no measles or mumps IgM was found.

Herpes simplex virus-specific IgM (herpes simplex IgM) was distributed among all three groups. Anticellular IgM was also found, predominantly in active multiple sclerosis, and persisted in two sera for two and a half years.

\section{Introduction}

Many authors have found an association between multiple sclerosis and measles antibody (Adams et al., 1970), while C. A. C. Ross et al. (1965) found an association with varicella-zoster antibody.

Royal Victoria Hospital, Belfast BT12 6BA

J. H. D. MILLAR, M.D., F.R.C.P., Consultant Neurologist

Department of Microbiology, The Queen's University of Belfast, Belfast BT12 6BN

K. B. FRASER, M.D., Professor of Microbiology

MARGARET HAIRE, M.D., Senior Experimental Officer

P. V. SHIRODARIA, B.SC., Research Assistant

DIANA S. M. HADDEN, M.B., D.C.H., Research Assistant
Unfortunately, conventional serological tests do not readily differentiate between past and persistent infection, but we have found that the amount of virus-specific $\operatorname{IgM}$ in a patient's serum, which characteristically increases in the first few days then disappears six to eight weeks after uncomplicated infection (Brown et al., 1970), remains raised during the course of certain complications of rubella (Haire and Hadden, 1970). We believe, by analogy with the congenital rubella syndrome in which rubella virus and rubella IgM coexist for long periods (Baublis and Brown, 1968; Vesikari et al., 1969) and also by analogy with subacute sclerosing panencephalitis, where measles antigen was shown to be present in the brain (Connolly et al., 1967) and was associated with persistent measles IgM (Connolly et al., 1971), that persistent virus-specific IgM is presumptive evidence of the presence of virus antigen.

For these reasons we decided to look for virus-specific IgM in sera from multiple sclerosis.

\section{Patients, Materials, and Methods}

Sera were collected from three groups each of 43 patients, matched for sex and consisting of 20 males and 23 females. One group of patients had multiple sclerosis, another had various neurological disorders, and the third "control" group was composed of healthy individuals. The multiple sclerosis patients and the normal controis were also matched for age, to the nearest two years.

Four categories of multiple sclerosis were defined: category 1, probable multiple sclerosis, active, 27 patients; category 2, probable multiple sclerosis, chronic, six patients; category 3 , possible multiple sclerosis, active, four patients; and category 4 , possible multiple sclerosis, chronic, six patients. "Probable" refers to a typical history of relapses and remissions and/or evidence of more than one lesion in the central nervous system. "Possible" refers to the early stage of the disease or spastic paraparesis without other ascertainable cause. "Active" means that the disease is in relapse or in an active progressive phase. "Chronic" means that the condition remains unchanged.

The 43 patients suffering from other neurological diseases consisted of 16 patients who had Parkinsonism, 7 who had cerebrovascular disease, 7 who had motor neurone disease, 8 who had epilepsy, and the remaining 5 each had a different disease.

The normal control sera were taken from healthy individuals, including patients reporting with injuries at a casualty department.

The sera were coded so that the persons doing the tests did not know the origin of any serum. The multiple sclerosis sera were stored at minus $20^{\circ} \mathrm{C}$ for periods of up to three years. All other sera were stored for two months before testing. Following the preliminary survey four selected patients from the multiple sclerosis group were bled again for confirmatory tests.

A 1 in 5 dilution of patient's serum, heated at $60^{\circ} \mathrm{C}$ for 30 minutes to remove non-specific reactants and adsorbed once with appropriate cells, was tested by the indirect immunofluorescent techniques and controls already described (Haire and Hadden, 1970) for IgG and IgM staining of measles-infected HEp2 cells and IgM staining of mumps-infected or herpes simplex-infected mouse $\mathrm{L}$ cells. Titration of specific IgG and IgM was carried out when required. 
Results

All sera had IgG against measles. The IgM results are shown in Tables I and II. In the multiple sclerosis group four patients had measles $\operatorname{IgM}$ and two had mumps $\operatorname{IgM}$ in their sera; in the group of nervous diseases one patient with post-encephalitic Parkinsonism had measles IgM in his serum, whereas herpes simplex IgM was present in all groups, including the "normal" controls (Table I). The patients with multiple sclerosis who had measles and mumps IgM all belonged to category 1. Eight of the same group who had herpes simplex $\operatorname{IgM}$ belonged to category 1 , two to category 4 , and one to category 3 .

TABLE I-Number of Paticnts Whosc Sora Containcd Virus-:pocific Is

\begin{tabular}{|c|c|c|c|c|c|}
\hline \multirow{2}{*}{\multicolumn{3}{|c|}{ IgM Specific for }} & \multicolumn{3}{|c|}{ Clinical Groups } \\
\hline & & & $\begin{array}{l}\text { Multiple } \\
\text { Sclerosis }\end{array}$ & $\begin{array}{c}\text { Other Nervous } \\
\text { Disorders }\end{array}$ & $\begin{array}{l}\text { Normal } \\
\text { Controls }\end{array}$ \\
\hline $\begin{array}{l}\text { Measles } \quad \ldots \\
\text { Mumps } \\
\text { Herpes simplex }\end{array}$ & $\begin{array}{l}\ldots \\
\cdots \\
\cdots\end{array}$ & $\begin{array}{l}\ldots \\
\cdots\end{array}$ & $\begin{array}{r}4 \\
2 \\
11\end{array}$ & $\begin{array}{l}1 \\
0 \\
7\end{array}$ & $\begin{array}{l}0 \\
0 \\
7\end{array}$ \\
\hline No. of patients & $\ldots$ & . & 43 & 43 & 43 \\
\hline
\end{tabular}

TABLE II-Titres of Virus-specific $\operatorname{IgG}$ and $\operatorname{Ig} M$ in Two Multiple Sclerosis Patients

\begin{tabular}{|c|c|c|c|c|c|}
\hline \multirow{3}{*}{ Patient } & & \multicolumn{4}{|c|}{ Reciprocal of Antibody Titre } \\
\hline & & \multicolumn{2}{|c|}{ Scrum 1} & \multicolumn{2}{|c|}{ Serum 2} \\
\hline & & IgG & IgM & IgG & $\operatorname{IgM}$ \\
\hline $\begin{array}{l}\text { A. Measles-specific } \\
\text { B. Mumps-specific }\end{array}$ & $\begin{array}{l}\ldots \\
\cdots\end{array}$ & $\begin{array}{l}40 \\
20\end{array}$ & $\begin{array}{l}20 \\
20\end{array}$ & $\begin{array}{l}40^{*} \\
40^{*}+\end{array}$ & $\begin{array}{l}20^{*} \\
10^{*}+\end{array}$ \\
\hline
\end{tabular}

* Specimen ubtained two-and-a-half years later: total IgM $250 \mathrm{mg} / 100 \mathrm{ml}$ serum + Specimen olstained three years later: total IgM $70 \mathrm{mg} / 100 \mathrm{ml}$ serum.

The titres of virus-specific $\operatorname{IgG}$ and $\operatorname{IgM}$ in second specimens of two sera-one specific for measles and one for mumps -and the values for total IgM are given in Table II, which shows that virus-specific IgM was still present two and a half and three years later. Titres of the virus $\operatorname{IgM}$ in other multiple sclerosis sera ranged from 1 in 5 to 1 in 20 .

There was no cross-reactive staining between measles and mumps IgM, and the IgM staining factor was removed from the two sera of Table II by absorption with homologous virus but not with heterologous virus. The serum containing measles IgM had a slightly raised total IgM; the serum containing mumps IgM had not.

The results of fluorescent staining of cells are shown in Table III. Bright staining of cell membrane, of cytoplasm or nuclei, or mixtures of these effects, were seen in both virusinfected and uninfected human HEp2 and mouse $\mathrm{L}$ cells.

TABLE II-Number of Patients Whose Sera Had IgM Reacting with Human HEP2 Cells

\begin{tabular}{|c|c|c|c|}
\hline \multirow{2}{*}{$\begin{array}{c}\text { Specificity of } \\
\text { Anticellular IgM }\end{array}$} & \multicolumn{3}{|c|}{ Clinical Groups } \\
\hline & $\begin{array}{l}\text { Multiple } \\
\text { Sclerosis }\end{array}$ & $\begin{array}{l}\text { Other Nervous } \\
\text { Disorders }\end{array}$ & $\begin{array}{l}\text { Normal } \\
\text { Controls }\end{array}$ \\
\hline 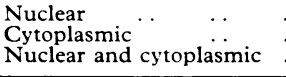 & $\stackrel{1}{21 *}$ & $\begin{array}{l}0 \\
5^{*} \\
1\end{array}$ & $\begin{array}{l}0 \\
1 \\
0\end{array}$ \\
\hline No. of patients & 43 & 43 & 43 \\
\hline
\end{tabular}

- Includes one patient who had IgG nuclear staining also.

Staining of cells was commonest in multiple sclerosis sera, less common in other nervous diseases, and was found only once in the group of "normal" control sera (Table III). With two exceptions the anticellular antibody was all $\operatorname{IgM}$ and 22 of the 27 sera from the multiple sclerosis group belonged to category 1 ; the remaining five were in the three other categories. Two sera from category 1 in the multiple sclerosis group, obtained two and a half years after the first specimen, gave the same anticellular staining as before. Anticellular staining was found in six patients who had other nervous diseases. Two of them had motor neurone disease.

\section{Discussion}

The principal features of the fluorescence results are the presence of measles $\operatorname{IgM}$ and mumps $\operatorname{IgM}$ in a small number of sera from multiple sclerosis patients, but not in sera from healthy individuals; the finding of anticellular $\operatorname{IgM}$ in a larger number of patient's sera; and the association of both these antibodies with active disease.

It is difficult to draw conclusions from a small number of observations but we believe that the findings are analogous to the association between intracerebral measles antigen and circulating measles IgM which has been reported in three patients who had subacute sclerosing panencephalitis (Connolly et al., 1971). The persistence of measles IgM for two and a half years and mumps IgM for three years in multiple sclerosis strengthens the comparison, and the even distribution among normal and pathological sera of $\operatorname{IgM}$ specific for herpes simplex virus, a recognized latent virus of man, supports the idea.

We do not think that a general hyperactivity of the immune response, which is another possible explanation of our findings, accounts for our detecting only mumps IgM or only measles $\operatorname{IgM}$ in a serum. One would expect IgM specific for several viruses to be raised to detectable levels in the same serum. More observations should clarify this point. Though one of our two multiple sclerosis sera tested had a raised total $\operatorname{IgM}$ it is worth noting that the incidence of sera showing increased amounts of total $\operatorname{IgM}$ has been reported as only $7.8 \%$ of 64 patients (Kolar et al., 1970).

The association of multiple sclerosis with measles and mumps suggests that one of several different viruses may be involved in the aetiology of the disease, which may account for the varied clinical picture. There is epidemiological evidence that multiple sclerosis may be acquired in childhood and, after a prolonged latency, become clinically manifest (Millar, 1971). Measles and mumps have been mentioned in this context (Kurtzke, 1968).

Only six multiple sclerosis patients had virus-specific IgM. This may indicate that our fluorescent antibody tests are not sensitive enough or that IgM specific for other viruses is present in some sera. The virus-specific IgM response could also be poor. Indeed, measles IgM titres in the multiple sclerosis group were much lower than those in subacute sclerosing panencephalitis (Connolly et al., 1971). It may be relevant that Svehag and Mandel (1964) showed experimentally that very much less antigen is required to induce an $\operatorname{IgM}$ response than is required for an IgG response and that the intensity of the response is related to the weight of antigen present.

The anticellular antibody in multiple sclerosis and other nervous diseases was, with two exceptions, all IgM. Most multiple sclerosis patients having anticellular $\operatorname{Ig} M$ were in the category of active disease. This may be related to a report that anti-brain IgM is present during the active stage of the disease (J. Ross et al., 1965). The variety of forms of anticellular staining and the fact that these were not confined to the sera of multiple sclerosis patients indicate that this immune response is not unique to multiple sclerosis.

Those viruses which bud through cell membranes, such as measles, mumps, herpes simplex and varicella zoster, are probably important in initiating antibody formation not only against the virus itself but also against components of the host cell which may be incorporated in or within the virus envelope. 
Immunofluorescent materials were supplied by a grant from the Multiple Sclerosis Society of Great Britain and Northern Ireland, and by the Medical Education and Research Committee of the Northern Ireland Hospitals Authority. One of us (D.S.M.H.) is engaged in a collateral study of these materials with rubella virus, supported by the National Fund for Research into Crippling Diseases. We wish to thank the doctors in charge of the patients; Mr. D. W. Neill, who measured immunoglobulins in sera; and Mrs. E. Gill and Miss Anne J. Fulton for technical help.

\section{References}

Adams, J. M. Brooks, M. B., Fisher, E. D., and Tyler, C. S. (1970). Neurology (Minneapolis), 20, 1039

Baublis, J. V., and Brown, G. C. (1968). Proceedings of the Socicty for Experimental Biology and Medicine, 128, 206.
Brown, G. C., Baublis, J. V., and O'Leary, T. P. (1970). Fournal of Immunology, 104, 86.

Connolly, J. H., Allen, I. V., Hurwitz, L. J., and Millar, J. H. D. (1967). Lancet, 1, 542.

Connolly, J. H., Haire, M., and Hadden, D. S. M. (1971). British Medical fournal, 1, 23.

Haire, M., and Hadden, D. S. M. (1970). British Medical fournal, 3, 130. Kolar, O. J., Ross, A. T., and Herman, J. T. (1970). Neurology (Minneapolis), 20, 1052.

Kurtzke, J. F. (1968). Neurology (Minneapolis), 18, Part 2, p. 170. Millar J. H. D., (1971). In Multiple Sclerosis: A Disease Acquired in Childhood. Springfield, Illinois, Thomas. In press.

Ross, C. A. C., Lenman, J. A. R., and Rutter, C. (1965). British Medical foumal, 1, 226.

Ross, J., Schumacher, K., and Mangete, E. (1965). Klinische Wochenschrift, 43, 1324.

Svehag S.-E., and Mandel, B. (1964). Fournal of Ixperimental Medicine, $119,1$.

Vesikari, T., Vahcri, A., Pettay, O., and Kunnas, M. (1969). Fournal of Pediatrics, 75, 658 .

\section{MEDICAL MEMORANDA}

\section{Dysgammaglobulinaemia Complicated by Disseminated Measles}

HELEN MAWHINNEY, INGRID V. ALLEN, J. M. BEARE, J. M. BRIDGES, J. H. CONNOLLY, MARGARET HAIRE, N. C. NEVIN, D. W. NEILL, J. R. HOBBS

\section{British Medical fournal, 1971, 2, 380-381}

We report the case of a boy with dysgammaglobulinaemia who died with giant cell pneumonia and disseminated measles seven weeks after receiving live attenuated measles vaccine.

\section{Case Report}

From the age of 6 weeks the patient had frequent infections associated with a rash on the face, scalp, and limbs. He was given three doses of triple antigen (diphtheria, pertussis, and tetanus) and oral live attenuated poliomyelitis vaccine; the third dose at the age of 8 months. Fifty-six days later live attenuated measles vaccine was given. One week later he developed a pyrexial illness with a skin rash. There was no known contact with measles. An elder brother had a similar illness when 2 days old and died at 7 months with staphylococcal bronchopneumonia, a cervical abscess, and boils on neck.
At 11 months the patient had an unusual skin rash, confluent on the face, extensive on the limbs, and less pronounced on the trunk (Figs. 1 and 2). This was hyperkeratotic, purpuric, and reticulate in pattern and was not that of eczema or measles. He had pyrexia, generalized lymphadenopathy, splenomegaly, nasal and urethral bleeding, oral thrush, and photophobia.

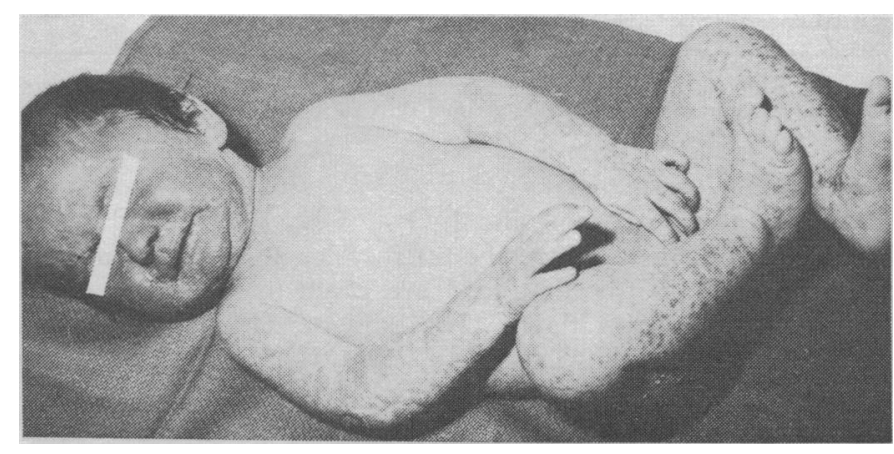

FIG. 1-Generalized symmetrical rash most pronounced on face and limbs.

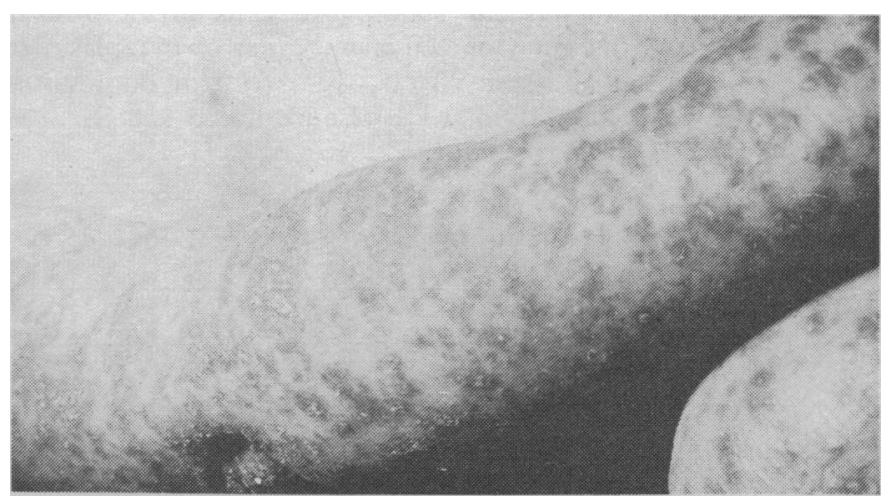

FIG. 2-Close-up showing reticulate and hyperkeratotic rash on the arm.

Rest Hostal for Sick Children, Belfast BT12 6

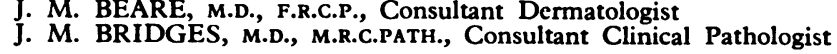

Royal Victoria Hospital, Belfast BT12 6BJ

J. H. CONNOLLY, M.D., M.R.C.PATH., Consultant Virologist

D. W. NEILL, M.SC., F.R.C.PATH., Consultant Biochcmist

Westminster Hospital Medical School, London S.W.1.

J. R. HOBBS, M.D., M.R.C.PATH., Professor of Immunology
Investigations.-Chest $x$-ray films showed progressive patchy consolidation of both mid-zones. Haemoglobin was $10.7 \mathrm{~g} / 100 \mathrm{ml}$ but fell terminally to $7.7 \mathrm{~g} / 100 \mathrm{ml}$. The platelet count ranged from 64,000 to $40,000 / \mathrm{mm}^{3}$. The initial total white cell count was $5,300 /$ $\mathrm{mm}^{3}$, with 3,000 lymphocytes $/ \mathrm{mm}^{3}$, but fell to $1,900 / \mathrm{mm}^{3}$, with 600 lymphocytes $/ \mathrm{mm}^{3}$. A skin biopsy showed patchy dyskeratosis, 